\title{
Cannabinoid 2 Receptor- and Beta Arrestin 2-Dependent Upregulation of Serotonin 2A Receptors
}

\author{
J.M. Franklin ${ }^{a}$, T. Vasiljevik ${ }^{b}$, T.E. Prisinzano $^{b}$, and G.A. Carrasco ${ }^{a},{ }^{*}$ \\ aDepartment of Pharmacology and Toxicology, University of Kansas, 1251 Wescoe Hall Drive, \\ 3048B Malott Hall, Lawrence, KS 66045 \\ bDepartment of Medicinal Chemistry, University of Kansas, 1251 Wescoe Hall Drive, 3048B \\ Malott Hall, Lawrence, KS 66045
}

\section{Abstract}

Recent evidence suggests that cannabinoid receptor agonists may regulate serotonin $2 \mathrm{~A}\left(5-\mathrm{HT}_{2 \mathrm{~A}}\right)$ receptor neurotransmission in the brain, although no molecular mechanism has been identified. Here, we present experimental evidence that sustained treatment with a non-selective cannabinoid agonist (CP 55,940) or selective CB2 receptor agonists (JWH 133 or GP 1a) upregulate 5-HT2A receptors in a neuronal cell line. Furthermore, this cannabinoid receptor agonist-induced upregulation of 5- $\mathrm{HT}_{2 \mathrm{~A}}$ receptors was prevented in cells stably transfected with either $\mathrm{CB} 2$ or $\beta$ Arrestin 2 shRNA lentiviral particles. Additionally, inhibition of clathrin-mediated endocytosis also prevented the cannabinoid receptor-induced upregulation of $5-\mathrm{HT}_{2 \mathrm{~A}}$ receptors. Our results indicate that cannabinoid agonists might upregulate $5-\mathrm{HT}_{2 \mathrm{~A}}$ receptors by a mechanism that requires CB2 receptors and $\beta$-Arrestin 2 in cells that express both $\mathrm{CB} 2$ and $5-\mathrm{HT}_{2 \mathrm{~A}}$ receptors. 5$\mathrm{HT}_{2 \mathrm{~A}}$ receptors have been associated with several physiological functions and neuropsychiatric disorders such as stress response, anxiety \& depression and schizophrenia. Therefore, these results might provide a molecular mechanism by which activation of cannabinoid receptors might be relevant to some cognitive and mood disorders in humans.

(C) 2012 Elsevier B.V. and European College of Neuropsychopharmacology. All rights reserved.

*Correspondence: Gonzalo A. Carrasco, PhD, Department of Pharmacology and Toxicology, University of Kansas, School of Pharmacy, 1251 Wescoe Hall Drive, 3048B Malott Hall, Lawrence, KS 66045, Phone: 785-864-1974, Fax: 785-864-5219, carrasco@ku.edu.

Publisher's Disclaimer: This is a PDF file of an unedited manuscript that has been accepted for publication. As a service to our customers we are providing this early version of the manuscript. The manuscript will undergo copyediting, typesetting, and review of the resulting proof before it is published in its final citable form. Please note that during the production process errors may be discovered which could affect the content, and all legal disclaimers that apply to the journal pertain.

Conflict of Interest Statement:

All the authors declare that there is no conflict of interest.

Author Individual Contribution:

1. Ms Jade Franklin, performed the in vitro experiments in CLU213 cells, and contributed to the experimental design, analysis of the data, and writing of the manuscript.

2. Ms Tamara Vasiljevik synthesized some of the cannabinoid agonists used in this manuscript and contributed to the discussion of the experimemtal results.

3. Dr Tom Prisinzano synthesized some of the cannabinoid agonists used in this manuscript and contributed to the discussion of the experimemtal results.

4. Dr. Gonzalo Carrasco, contributed to the experimental design, analysis of the data, and writing of the manuscript. Dr. Carrasco is the PI for the grants supporting this manuscript (NIDA and University of Kansas Startup Funds).

All authors contributed to and have approved the final manuscript. 


\section{Keywords}

cannabinoids; $\mathrm{CB} 2$ receptors; serotonin; marijuana; $\beta$-Arrestins; receptor internalization; $5-\mathrm{HT}_{2 \mathrm{~A}}$ receptor

\section{Introduction}

Marijuana (Cannabis sativa L.) is the most commonly abused illicit drug in the United States (National Institute on Drug Abuse (NIDA) ,2009). According to recent epidemiological data, marijuana and synthetic cannabinoids are the most prevalent illicit drugs used by $12^{\text {th }}$ graders in the United States (Cesar Fax ,2012). Indeed, more than one-third (36.4\%) of high school seniors reported using marijuana in 2011, including $11.4 \%$ who reported using synthetic cannabinoids (Cesar Fax ,2012).

Cannabinoid agonists produce their effects by acting upon two cannabinoid receptors in the brain, CB1 and CB2 receptors (Shoemaker et al. 2005; Atwood and Mackie ,2010;Bouaboula et al. 1996). These receptors bind endocannabinoids and exogenous cannabinoids (such as $\Delta$ 9-THC) with high affinity (Bouaboula et al. 1996; Felder et al. 2006). CB1 and CB2 receptors, which couple to Gai/o class of G-proteins, have presynaptic or postsynaptic distribution in the brain (Onaivi et al. 2006;Felder et al. 2006;Kawamura et al. 2006;Brusco et al. 2008). Furthermore, these receptors can activate ERK1/2 signaling possibly through a $\beta$-Arrestin 2 ( $\beta$-Arr2) dependent pathway (Atwood and Mackie ,2010;Bouaboula et al. 1996).

Behavioral reports have suggested that cannabinoid receptor agonists can regulate the activity of serotonin $2 \mathrm{~A}\left(5-\mathrm{HT}_{2 \mathrm{~A}}\right)$ receptors (Darmani ,2001; Hill et al. 2006). However, the molecular mechanism by which cannabinoid regulates $5-\mathrm{HT}_{2 \mathrm{~A}}$ receptor signaling in the brain is unknown. $5-\mathrm{HT}_{2 \mathrm{~A}}$ receptors, which regulate the dopamine mesoaccumbens pathway, play an important role in the regulation of stress, mood and impulse control and the behavioral effects of several drugs of abuse (Bubar and Cunningham ,2006; Carrasco and Van de Kar ,2003). Furthermore, impaired function of cortical 5-HT $2 \mathrm{~A}$ receptors has been identified in several neurological and psychiatric disorders such as schizophrenia, Alzheimer's disease, depression, anxiety, and eating disorders (Roth ,2011).

Here, we studied some mechanisms involved in the cannabinoid-induced upregulation of 5$\mathrm{HT}_{2 \mathrm{~A}}$ receptors in a neuronal cell line. Our results support the cannabinoid-induced upregulation of 5- $\mathrm{HT}_{2 \mathrm{~A}}$ receptors through a $\mathrm{CB} 2$ receptors and $\beta$-Arr2-dependent mechanism.

\section{Experimental Procedures}

\section{Cell Culture Protocol}

CLU213 cells, a rat neuronal cell line, were purchased from Cedarlane Laboratories (Burlington, NC). Cells were grown on $100-\mathrm{mm}^{2}$ plates treated with polystyrene (Corning Incorporated, Corning, $\mathrm{NY}$ ) and maintained in $5 \% \mathrm{CO}_{2}$ at $37^{\circ} \mathrm{C}$, in Dulbecco's modified eagle medium (Mediatech Inc, Manassas,VA) containing 10\% fetal bovine serum (Thermo Scientific, Logan, UT).

\section{Quantitative Real-Time PCR}

These reactions were prepared using QuantiFast SYBR Green PCR Kit (Qiagen, Valencia, CA) and the ABI 7500 fast real time PCR system (Applied Biosystems, Foster City, CA) as previously described (Singh et al. 2010). The primers used in this manuscript were: $5-\mathrm{HT}_{2 \mathrm{~A}}$ 
(F:5'-AACGGTCCATCCACAGAG-3', R:5' -AACAGGAAGAACACGATGC-3'), CB2 (F: '5-CCAACATGTAGCCAGCTTGACT-3',R: 5'-TGCAGGAACCAGCATATGA-3') $\beta$ Arr2 (F:5'-AGCACCGCGCAGTACAAGT-3',5'-R:CACGCTTCTCTCGGTTGTCA-3'), and GAPDH (F:5'-TGGAGTCTACTGGCGTCTTCAC-3',R:5'-

GGCATGGACTGTGGTCATGA-3'). These primers have been validated in the literature (Mato et al. 2009; Singh et al. 2010; Yang et al. 2011).

In all real-time PCR experiments, measurements were made from the number of cycles required to reach the threshold fluorescence intensity [cycle threshold $(\mathrm{Ct})]$. $\mathrm{Ct}$ values for each reaction were subtracted from $\mathrm{Ct}$ values for GADPH and then subtracted from $\mathrm{Ct}$ values for vehicle-treated controls that served as a baseline, and the result was referred to as $\Delta \Delta \mathrm{Ct}$. Fold changes in gene expression were calculated as $2-\Delta \Delta \mathrm{Ct}$ to reflect the fact that, under optimal conditions, the amount of PCR product doubles with each amplification cycle. Results were normalized to those obtained for amplifications of the same cDNA samples using primers designed against GADPH, which acts as an internal standard, and averaged for each treatment group.

To study the effect of non-selective and selective cannabinoid receptor agonists on 5-HT2A mRNA, CLU213 cells were incubated with either vehicle (ethanol $0.01 \%$ final concentration), CP 55,940 $1 \mathrm{nM}$ (non-selective CB1/CB2 agonist, $\mathrm{K}_{\mathrm{i}}: 0.58 \mathrm{nM}$ and $0.68 \mathrm{nM}$ for CB1 and CB2 receptors, respectively) (Showalter et al. 1996;Atwood et al. 2012); ACEA $15 \mathrm{nM}$ (selective CB1 agonist, $\mathrm{K}_{\mathrm{i}}: 1.4 \mathrm{nM}$ and $3.1 \mu \mathrm{M}$ for CB1 and CB2 receptors, respectively) (Hillard et al. 1999;Rutkowska and Jachimczuk ,2004); GP 1a $1 \mathrm{nM}$ (highly selective $\mathrm{CB} 2$ agonist, $\mathrm{K}_{\mathrm{i}}: 0.037 \mathrm{nM}$ and $353 \mathrm{nM}$ for CB2 and CB1 receptors, respectively) (Gorantla et al. 2010), or JWH $13330 \mathrm{nM}$ (selective CB2 agonist, $\mathrm{K}_{\mathrm{i}}: 3.4 \mathrm{nM}$ and $677 \mathrm{nM}$ for CB2 and CB1 receptors, respectively ) (Huffman et al. 1999;Griffin et al. 1997) for 24 hours. In the Concanavalin A (ConA) experiment, cells were pretreated with $250 \mu \mathrm{g} / \mathrm{ml}$ ConA for 20 minutes (Trincavelli et al. 2000) and then treated with different cannabinoid agonists.

In a separate experiment utilized to examine the effect of an aminoakylindole on 5- $\mathrm{HT}_{2 \mathrm{~A}}$ receptor mRNA levels, cells were treated with either vehicle (ethanol $0.01 \%$ final concentration), GP 1a $1 \mathrm{nM}$, CP 559,940 $1 \mathrm{nM}$, or JWH $07340 \mathrm{nM}$ (mildly selective CB1 receptor agonist, $\mathrm{K}_{\mathrm{i}}: 8.9 \mathrm{nM}$ and $38 \mathrm{nM}$ for $\mathrm{CB} 1$ and $\mathrm{CB} 2$ receptors, respectively) (Aung et al. 2000;Huffman et al. 2005) for 24 hours. In the Concanavalin A (ConA) experiment, cells were pretreated with $250 \mu \mathrm{g} / \mathrm{ml}$ ConA for 20 minutes (Trincavelli et al. 2000) and then treated with different cannabinoid agonists.

\section{Western Blot}

Membrane-associated and cytosolic-associated fractions were isolated using the ProteoExtract ${ }^{\mathrm{TM}}$ Native Membrane Protein Extraction kit (Calbiochem, La Jolla, CA). Nuclear-associated fractions were isolated using NE-PER ® Nuclear and Cytoplasmic Extraction Reagents (Thermo Scientific, IL). Expression of membrane-associated 5- $\mathrm{HT}_{2 \mathrm{~A}}$ receptors, CB2 receptors, $\beta$-Arr2, and nuclear-associated pERK was determined by Western blot as previously described (Carrasco et al. 2006). The anti-5-HT $2 \mathrm{~A}$ receptor antibody was a generous gift from Dr. Nancy A. Muma and the specificity of this antibody has been validated in the literature (Singh et al. 2007). CB2 receptor, $\beta$-Arr2, and pERK antibody were purchased from Santa Cruz, CA. Protein loading for each lane was verified using an anti-actin antibody (Santa Cruz Biotechnology, Inc.). Negative controls included either the omission of primary antibody or addition of preimmune rabbit immunoglobulins. Films were analyzed densitometrically as described (Carrasco et al. 2006). All samples were standardized to controls and normalized to their respective actin levels. 
To study the effect of GP1a, CP 55940, or ACEA on membrane-associated 5-HT2A receptor levels, CLU213 cells were treated with either vehicle (ethanol $0.01 \%$ final concentration), GP1a (1nM), CP 55,940 (1 nM) or ACEA (15 nM) for 72 hours. Cells were washed with PBS every 24 hours and fresh vehicle, GP1a, CP55,940 or ACEA was added. To study the effect of ConA on cytosolic-associated CB2 or nuclear-associated pERK levels, cells were pretreated with ConA $(250 \mu \mathrm{g} / \mathrm{ml})$ and then 20 minutes later treated with either vehicle, GP1a (1nM), or CP55,940 (1nM) for 15 minutes.

\section{Lentivirus and stable transduction of shRNAs in CLU213 cells}

$\beta$-Arrestin 2 shRNA (r), CB2 shRNA (r), copGFP control, control shRNA lentiviral particles, polybrene, and puromyocin were purchased from Santa Cruz, CA. Optimal transduction conditions were elucidated utilizing copGFP control lentiviral particles prior to transduction with $\beta$-Arrestin 2 shRNA or CB2 shRNA lentiviral particles. Once optimal transduction conditions had been defined, CLU213 cells in 24-well plates ( 2 X 104 cells/ well) were infected with either control, $\beta$-Arrestin 2 , or CB2 shRNA lentivirial particles at a multiplicity of infection (MOI) of 2 in complete medium containing a final concentration of $2 \mu \mathrm{g} / \mathrm{ml}$ of Polybrene. 48 hours post-infection, medium was changed to a virus-free complete medium (no polybrene). Puromyocin ( $2 \mu \mathrm{g} / \mathrm{ml}$ final concentration) selection was initiated 24 hours later. Cells were analyzed for $\beta$-Arrestin 2 or CB2 knockdown one week after initiation of puromyocin selection.

\section{Statistics}

All data are expressed as the mean \pm S.E.M. Each experiment was run in triplicate. Data was analyzed by an unpaired Student's t-test or ANOVA (Newman-Keuls post-hoc test).

\section{Results}

Cells treated with either CP55,940 (CB1/CB2 agonist), GP1a (CB2 agonist) or JWH133 $\left(\mathrm{CB} 2\right.$ agonist) showed significant $(\mathrm{p}<0.01)$ increases in $5-\mathrm{HT}_{2 \mathrm{~A}}$ mRNA levels compared to vehicle-treated controls (Fig.1A). However, no significant changes were detected in cells treated with ACEA, selective CB1 agonist. Next we determined the effect of CP 55,940 (1 $\mathrm{nM})$, ACEA $(15 \mathrm{nM})$ and $\mathrm{GP} 1 \mathrm{a}(1 \mathrm{nM})$ on membrane-associated $5-\mathrm{HT}_{2 \mathrm{~A}}$ receptor protein levels. GP1a exhibits higher selectivity for CB2 receptors than JWH133 therefore we utilized GP 1a to assess whether a highly selective CB2 receptor agonist would increase 5$\mathrm{HT}_{2 \mathrm{~A}}$ receptor protein levels (approx. 9,000- and 200-fold selectivity between CB2/CB1 receptors, respectively) (Gorantla et al. 2010;Griffin et al. 1997). We found that CP 55,940 treatment and GP1a treatment significantly $(\mathrm{p}<0.01)$ increased membrane-associated 5$\mathrm{HT}_{2 \mathrm{~A}}$ receptor protein levels $(61 \pm 10 \%$ and $72 \pm 10 \%$ increase, respectively)(Fig. $1 \mathrm{~B}$ and Fig. 1D). Treatment with ACEA did not significantly ( $>0.05)$ modify the membrane-associated 5- $\mathrm{HT}_{2 \mathrm{~A}}$ receptor protein levels compared to controls (Fig. 1C).

We used cells stably transfected with CB2 or control shRNA lentiviral particles to study whether the effect of cannabinoid agonists is mediated by CB2 receptors. CB2 shRNA lentiviral particle treatment significantly $(\mathrm{p}<0.01)$ reduced both $\mathrm{CB} 2 \mathrm{mRNA}(\mathrm{Fig} .2 \mathrm{~A})$ and protein levels (Fig. 2B) by approximately $80 \%$ compared to control-treated cells. CP55,940, JWH133, and GP1a upregulated 5- $\mathrm{HT}_{2 \mathrm{~A}}$ mRNA in control shRNA cells $(85 \pm 5 \%, 84 \pm 5 \%$ and $84 \pm 5 \%$ increase in 5- $\mathrm{HT}_{2 \mathrm{~A}} \mathrm{mRNA}$, respectively). Noteworthy, cells stably transfected with CB2 shRNA showed no CP55,940, GP1a, or JWH133-induced increases in 5-HT2A mRNA levels (Fig. 2C). The two-way ANOVA showed main effects of transfection $\left(\mathrm{F}_{1,173}\right.$ $=2.20, \mathrm{p}<0.0001), \mathrm{CB} 2$ agonists $\left(\mathrm{F}_{3,15.5}=0.1974, \mathrm{p}<0.0001\right)$, and a main interaction between these two factors $\left(\mathrm{F}_{3,27.66}=0.35, \mathrm{p}<0.0001\right)$ on $5-\mathrm{HT}_{2 \mathrm{~A}}$ mRNA levels. 
We also used cells stably transfected with either $\beta$-Arr2 or control shRNA lentiviral particles to study the contribution of $\beta$-Arr 2 on the cannabinoid-induced upregulation of 5- $\mathrm{HT}_{2 \mathrm{~A}}$ receptors. Treatment with $\beta$-Arr2 shRNA lentiviral particles significantly $(\mathrm{p}<0.01)$ reduced both $\beta$-Arr2 mRNA (Fig. 3A) and protein levels (Fig. 3B) by approximately $85 \%$. CP55,940, JWH133, and GP1a upregulated 5- $\mathrm{HT}_{2 \mathrm{~A}}$ mRNA in control shRNA treated cells by $94 \pm 10 \%, 84 \pm 10 \%$ or $95 \pm 7 \%$, respectively. The cannabinoid agonist-induced upregulation of 5-HT $2 \mathrm{~A}$ mRNA levels was significantly $(\mathrm{p}<0.05)$ reduced in cells stably transfected with $\beta$-Arr2 shRNA lentiviral particles. CP55,940-, JWH133-, or GP1a-mediated increases in $5-\mathrm{HT}_{2 \mathrm{~A}}$ mRNA levels was $19 \pm 9 \%, 0 \pm 2 \%$ or $40 \pm 10 \%$, respectively (Fig. $3 \mathrm{C})$. There was no significant difference $(\mathrm{p}>0.05)$ in the response mediated by either CP55,940 and JWH133. However, treatment with GP 1a significantly $(\mathrm{p}<0.05)$ increased 5$\mathrm{HT}_{2 \mathrm{~A}}$ receptor mRNA levels in CB2 shRNA lentivirus treated cells compared to vehicle treated controls. The two-way ANOVA showed main effects of transfection $\left(\mathrm{F}_{1,40.47}\right.$ $=1.66, \mathrm{p}<0.0001), \mathrm{CB} 2$ agonists $\left(\mathrm{F}_{3,13.92}=0.574, \mathrm{p}<0.0001\right)$, and a main interaction between these two factors $\left(\mathrm{F}_{3,4.12}=0.17, \mathrm{p}<0.025\right)$ on $5-\mathrm{HT}_{2 \mathrm{~A}}$ mRNA levels.

We then investigated whether $\mathrm{CB} 2$ receptor internalization is involved in the cannabinoid agonist-induced upregulation of $5-\mathrm{HT}_{2 \mathrm{~A}}$ receptors. Different methods are commonly used to prevent clathrin-mediated internalization of receptors such as ConA treatment, use of hypertonic sucrose, or depletion of intercellular potassium (Trincavelli et al. 2000; Macey et al. 2010). We pretreated cells with vehicle or ConA prior to treatment with either vehicle, CP55,940 or GP1a. As expected, CP55,940 and GP1 a significantly upregulated 5-HT2A mRNA levels compared to vehicle treated cells (approximately $90 \%$ increase, Fig.4A). ConA pretreatment significantly ( $\mathrm{p}<0.01)$ blocked the effect of CP55,940 $(-9 \pm 2 \%$ reduction) and GP1a $\left(-5 \pm 2 \%\right.$ reduction) on $5-\mathrm{HT}_{2 \mathrm{~A}} \mathrm{mRNA}$ levels compared to controls (Fig.4A). The two-way ANOVA showed a main effect of ConA $\left(\mathrm{F}_{1,146.47}=2.22, \mathrm{p}<0.0001\right)$, CB2 agonists $\left(F_{2,28.95}=0.437, p<0.0001\right)$, and a main between these two factors $\left(F_{2,26.10}\right.$ $=0.394, \mathrm{p}<0.0001)$ on $5-\mathrm{HT}_{2 \mathrm{~A}}$ mRNA levels.

We then evaluated whether ConA pretreatment can modify the agonist-induced cytosolic localization of CB2 receptors in a neuronal cell line. We isolated cytosolic fractions from cells pretreated with vehicle or ConA and then treated with either vehicle, CP55,940 or GP1a. Control cells treated with either CP55,940 or GP 1a showed significant increases in the cytosolic levels of CB2 receptors (112 $\pm 30 \%$ and $90 \pm 9 \%$, respectively) compared to controls (Fig.4B). ConA pretreatment significantly ( $<<0.01)$ reduced the vehicle, CP55,940and GP1a-induced increases in CB2 cytosolic levels. Furthermore, CP 55,940 treatment in the ConA pretreated cells significantly increased $\mathrm{CB} 2$ receptor cytosolic levels compared to ConA/Vehicle or ConA/GP 1a treated cells. The cytosolic CB2 levels were: $32 \pm 7 \%, 7.5 \pm$ $2 \%, 85 \pm 13 \%$ for vehicle, GP1a and CP55,940 treated cells, respectively. The two-way ANOVA showed a main effect of ConA pretreatment $\left(\mathrm{F}_{1,129}=83831, \mathrm{p}<0.0001\right), \mathrm{CB} 2$ agonist treatment $\left(\mathrm{F}_{2,19.28}=12.465, \mathrm{p}<0.0001\right)$, and a main interaction between these two factors $\left(\mathrm{F}_{2,8.909}=5760, \mathrm{p}<0.025\right)$ on $\mathrm{CB} 2$ cytosolic levels.

Recent evidence shows that some cannabinoid ligands are more efficacious CB2 receptor internalizers than others (Atwood et al. 2012). While CP55,940 is a classified as a good CB2 receptor internalizer, JWH-073 would classify as a poor CB2 receptor internalizer (Atwood et al. 2012). There is no data regarding the properties of GP1a (Atwood et al. 2012). We then tested the effect of either vehicle, JWH-073, GP1a or CP55,940 on 5-HT $2 \mathrm{~A}$ mRNA levels in cells (Fig. 4C). We found that both GP1a and CP55,940 treatment produced significant $(\mathrm{p}<0.01)$ increases in the $5-\mathrm{HT}_{2 \mathrm{~A}}$ mRNA levels $(110 \pm 8 \%$ and $90 \pm 7 \%$, respectively) but JWH-073 did not have any effect. 
CB2 internalization might also play a role in ERK1/2 activation (Lefkowitz and Shenoy, 2005). Indeed, $\mathrm{CB} 2$ receptors might upregulate 5- $\mathrm{HT}_{2 \mathrm{~A}}$ receptors via activation of ERK1/2 (Chang et al. 2003). We studied the effect of ConA pretreatment on ERK1/2 activation by measuring nuclear levels of pERK protein in cells treated with either vehicle or GP1a. Significant $(\mathrm{p}<0.05)$ increases in the nuclear levels of pERK ( $35 \pm 3 \%$ compared to controls) were found in GP1 a treated cells (Fig. 4D). ConA pretreatment significantly reduced the basal and GP1a-induced increases in nuclear-associated pERK levels (Fig. 4D). The twoway ANOVA showed a main effect of ConA pretreatment $\left(\mathrm{F}_{1,829}=55647, \mathrm{p}<0.0001\right)$, GP1a treatment $\left(\mathrm{F}_{2,30.60}=2052, \mathrm{p}<0.0001\right)$ and a main interaction between these two factors $\left(\mathrm{F}_{1,6.53}=438, \mathrm{p}<0.021\right)$ on nuclear $\mathrm{pERK}$ levels.

\section{Discussion}

CB2 receptors are located not only in the periphery but also in several brain areas including prefrontal cortex, hippocampus, amygdala, etc (Onaivi et al. 2008; den Boon et al. 2012;Gong et al. 2006;Garcia-Gutierrez et al. 2010). Furthermore, recent studies reported that CB2 receptors are mainly localized post-synaptically (Onaivi et al. 2006; Brusco et al. 2008). These recent findings have led to a re-evaluation of the roles of $C B 2$ receptors in the brain. Interestingly, here we found that a potent non-selective cannabinoid agonist (CP55,940) and selective CB2 receptor agonists (JWH133 and GP1a) induced a strong upregulation of 5- $\mathrm{HT}_{2 \mathrm{~A}}$ receptors in neuronal cells. This cannabinoid-induced upregulation was not mimicked by a CB1 agonist (ACEA) and was absent in cells stably transfected with CB2 shRNA (Fig.2) indicating that CB2 receptors are required for this cannabinoidmediated upregulation of $5-\mathrm{HT}_{2 \mathrm{~A}}$ receptors.

Accumulating evidence shows that different $\mathrm{CB} 2$ receptor agonists can distinctly regulate multiple effector pathways, a phenomenon known as functional selectivity (Atwood et al. 2012; Lefkowitz and Shenoy ,2005; Shoemaker et al. 2005). This transmission of extracellular signals to the interior of the cell is a function of plasma membrane receptors that can direct the recruitment, activation, and scaffolding of cytoplasmic signaling complexes via $\beta$-arrestins (Lefkowitz and Shenoy ,2005). Specifically, a $\beta$-Arr 2 dependent pathway could mediate the CB2-induced activation of ERK1/2 signaling and the internalization of CB2 receptors (McGuinness et al. 2009; Atwood et al. 2012). Our results support a key role of $\beta$-Arr2 in the cannabinoid-induced upregulation of $5-\mathrm{HT}_{2 \mathrm{~A}}$ receptors as cells stably transfected with $\beta$-Arr2 shRNA lentivirus (Fig. 3) failed to upregulate 5-HT2A receptors in response to either CP55,940 or JWH133. GP 1a-mediated upregulation of 5$\mathrm{HT}_{2 \mathrm{~A}}$ mRNA levels was significantly reduced in $\beta$-Arr2 shRNA lentivirus treated cells compared to control shRNA treated cells. Although, we do not know the mechanism mediating this effect we speculate that the remaining $\beta$-Arr2 protein levels (approx.15-20\%) could be enough to produce significant increases in $5-\mathrm{HT}_{2 \mathrm{~A}}$ mRNA levels. Alternatively, GP $1 \mathrm{a}$ could be triggering this upregulation (at least in part) through a different signaling mechanism than the one triggered by CP55,940 or JWH 133.

$\beta$-Arr2 could mediate the upregulation of $5-\mathrm{HT}_{2 \mathrm{~A}}$ receptors by regulating internalization of CB2 receptors (Atwood et al. 2012). ConA pretreatment of cultured cells is used to prevent clathrin-mediated internalization of receptors (Trincavelli et al. 2000; Macey et al. 2010). Interestingly, ConA pretreatment prevented the CP55,940- and GP1a-induced increases in 5$\mathrm{HT}_{2 \mathrm{~A}}$ receptor mRNA levels in cultured cells (Fig.4A). Our results also showed that ConA pretreatment also prevented the CP55,940 or GP1 a increases in CB2 receptor cytosolic levels (Fig.4B). Noteworthy, ConA pretreatment even reduced the basal cytosolic CB2 protein levels (Fig.4B). This suggests that ConA might prevent the basal trafficking of CB2 receptors between the membrane and cytosol in neuronal cells. Similarly, Atwood et al (2012) described significant increases in membrane-associated levels of CB2 receptors in 
sucrose treated cells (Atwood et al. 2012) further indicating that protocols utilized to prevent clathrin-mediated endocytosis alter basal trafficking of the CB2 receptors between the membrane and the cytosol.

The previous experiments suggest that the degree of internalization of CB2 receptors could play an important role in the upregulation of 5- $\mathrm{HT}_{2 \mathrm{~A}}$ receptors. Atwood et al. (2012) identified different classes of CB2 agonists that differ substantially in their ability to promote CB2 receptor internalization (Atwood et al. 2012). Cannabinoid agonists such as CP55,940 and JWH133 were the most efficacious CB2 receptor internalizers, while aminoalkylindoles which include cannabinoid ligands, such as JWH-073 and WIN55,212-2, were the least effective or failed to promote CB2 receptor internalization (Atwood et al. 2012). We found that CP55,940, but not JWH-073, induced 5-HT $2 \mathrm{~A}$ upregulation (Fig. 4C), suggesting that upregulation of $5-\mathrm{HT}_{2 \mathrm{~A}}$ receptors is dependent on the ability of the agonists to promote internalization of $\mathrm{CB} 2$ receptors. This is consistent with the experiments previously discussed where ConA pretreatment prevented the cannabinoid-mediated increases in 5-HT2A mRNA levels (Fig. 4A).

$\mathrm{CB} 2$ receptor-mediated upregulation of $5-\mathrm{HT}_{2 \mathrm{~A}}$ receptors might involve transcription factors that are located downstream of ERK and that target the promoter region of the 5- $\mathrm{HT}_{2 \mathrm{~A}}$ receptor gene such as CREB and AP-1 (Chang et al. 2003). Here, we found that a selective $\mathrm{CB} 2$ receptor agonist (GP1a) induced ERK1/2 activation (Fig. 4D), suggesting that the CB2 receptor mediated-upregulation of 5- $\mathrm{HT}_{2 \mathrm{~A}}$ receptors involve activation of the ERK1/2 signaling pathway.

In summary, our results indicate that cannabinoid agonists would upregulate $5-\mathrm{HT}_{2 \mathrm{~A}}$ receptors by a mechanism that requires $\mathrm{CB} 2$ receptors and $\beta$-Arr2 activation in cells that express both $\mathrm{CB} 2$ and 5- $\mathrm{HT}_{2 \mathrm{~A}}$ receptors. This upregulation could be mediated by a mechanism that involves internalization of $\mathrm{CB} 2$ receptors and ERK1/2 activation. Indeed, compounds that do not internalize CB2 receptors such as JWH-073 do not induce 5- $\mathrm{HT}_{2 \mathrm{~A}}$ upregulation. It is then possible that cannabinoid agonists that upregulate $5-\mathrm{HT}_{2 \mathrm{~A}}$ receptors mediate their effect by recruiting $\beta$-Arr 2 to the membrane, enhancing ERK1/2 activation, and also promoting $\mathrm{CB} 2$ receptor internalization. $5-\mathrm{HT}_{2 \mathrm{~A}}$ receptors have been associated with several physiological functions and neuropsychiatric disorders such as stress response, anxiety \& depression and schizophrenia (Roth ,2011;Carrasco and Van de Kar ,2003). Cannabinoid-induced upregulation of $5-\mathrm{HT}_{2 \mathrm{~A}}$ receptors may precipitate the onset of mental disorders associated with dysfunction of $5-\mathrm{HT}_{2 \mathrm{~A}}$ receptor neurotransmission as it has been recently suggested (Large et al. 2011).

\section{Acknowledgments}

This work was supported by National Institute of Health/National Institute on Drug Abuse DA024329 and University of Kansas Startup Funds. We would like to thank Ms. Heather Menchen for her valuable technical assistance in the lentivirus infection experiments.

\section{Author Disclosure:}

Funding for this study was provided by National Institute of Health/National Institute on Drug Abuse DA024329 and University of Kansas Startup Funds; Neither NIDA nor University of Kansas had a further role in study design; in the collection, analysis and interpretation of data; in the writing of the report; and in the decision to submit the paper for publication.

\section{Reference List}

Atwood BK, Mackie K. CB2: a cannabinoid receptor with an identity crisis. Br.J.Pharmacol. 2010; 160:467-479. [PubMed: 20590558] 
Atwood BK, Wager-Miller J, Haskins C, Straiker A, Mackie K. Functional selectivity in CB(2) cannabinoid receptor signaling and regulation: implications for the therapeutic potential of $\mathrm{CB}(2)$ ligands. Mol.Pharmacol. 2012; 81:250-263. [PubMed: 22064678]

Aung MM, Griffin G, Huffman JW, Wu M, Keel C, Yang B, Showalter VM, Abood ME, Martin BR. Influence of the N-1 alkyl chain length of cannabimimetic indoles upon $\mathrm{CB}(1)$ and $\mathrm{CB}(2)$ receptor binding. Drug Alcohol Depend. 2000; 60:133-140. [PubMed: 10940540]

Bouaboula M, Poinot-Chazel C, Marchand J, Canat X, Bourrie B, Rinaldi-Carmona M, Calandra B, Le FG, Casellas P. Signaling pathway associated with stimulation of CB2 peripheral cannabinoid receptor. Involvement of both mitogen-activated protein kinase and induction of Krox-24 expression. Eur.J.Biochem. 1996; 237:704-711. [PubMed: 8647116]

Brusco A, Tagliaferro PA, Saez T, Onaivi ES. Ultrastructural localization of neuronal brain CB2 cannabinoid receptors. Ann.N.Y.Acad.Sci. 2008; 1139:450-457. [PubMed: 18991892]

Bubar MJ, Cunningham KA. Serotonin 5-HT2A and 5-HT2C receptors as potential targets for modulation of psychostimulant use and dependence. Curr.Top.Med.Chem. 2006; 6:1971-1985. [PubMed: 17017968]

Carrasco GA, Van de Kar LD. Neuroendocrine pharmacology of stress. Eur.J.Pharmacol. 2003; 463:235-272. [PubMed: 12600714]

Carrasco GA, Van de Kar LD, Sullivan NR, Landry M, Garcia F, Muma NA, Battaglia G. Cocainemediated supersensitivity of 5-HT2A receptors in hypothalamic paraventricular nucleus is a withdrawal-induced phenomenon. Neuroscience. 2006; 143:7-13. [PubMed: 17055657]

Cesar Fax. 21 ed. 2012. p. 1-2.

Chang F, Steelman LS, Lee JT, Shelton JG, Navolanic PM, Blalock WL, Franklin RA, McCubrey JA. Signal transduction mediated by the Ras/Raf/MEK/ERK pathway from cytokine receptors to transcription factors: potential targeting for therapeutic intervention. Leukemia. 2003; 17:12631293. [PubMed: 12835716]

Darmani NA. Cannabinoids of diverse structure inhibit two DOI-induced 5-HT(2A) receptor-mediated behaviors in mice. Pharmacol.Biochem.Behav. 2001; 68:311-317. [PubMed: 11267636]

den Boon FS, Chameau P, Schaafsma-Zhao Q, van AW, Bari M, Oddi S, Kruse CG, Maccarrone M, Wadman WJ, Werkman TR. Excitability of prefrontal cortical pyramidal neurons is modulated by activation of intracellular type-2 cannabinoid receptors. Proc.Natl.Acad.Sci.U.S.A. 2012; 109:3534-3539. [PubMed: 22331871]

Felder CC, ckason-Chesterfield AK, Moore SA. Cannabinoids biology: the search for new therapeutic targets. Mol.Interv. 2006; 6:149-161. [PubMed: 16809476]

Garcia-Gutierrez MS, Perez-Ortiz JM, Gutierrez-Adan A, Manzanares J. Depression-resistant endophenotype in mice overexpressing cannabinoid CB(2) receptors. Br.J.Pharmacol. 2010; 160:1773-1784. [PubMed: 20649579]

Gong JP, Onaivi ES, Ishiguro H, Liu QR, Tagliaferro PA, Brusco A, Uhl GR. Cannabinoid CB2 receptors: immunohistochemical localization in rat brain. Brain Res. 2006; 1071:10-23. [PubMed: 16472786]

Gorantla S, Makarov E, Roy D, Finke-Dwyer J, Murrin LC, Gendelman HE, Poluektova L. Immunoregulation of a CB2 receptor agonist in a murine model of neuroAIDS. J.Neuroimmune.Pharmacol. 2010; 5:456-468. [PubMed: 20549374]

Griffin G, Fernando SR, Ross RA, McKay NG, Ashford ML, Shire D, Huffman JW, Yu S, Lainton JA, Pertwee RG. Evidence for the presence of CB2-like cannabinoid receptors on peripheral nerve terminals. Eur.J.Pharmacol. 1997; 339:53-61. [PubMed: 9450616]

Hill MN, Sun JC, Tse MT, Gorzalka BB. Altered responsiveness of serotonin receptor subtypes following long-term cannabinoid treatment. Int.J.Neuropsychopharmacol. 2006; 9:277-286. [PubMed: 15967059]

Hillard CJ, Manna S, Greenberg MJ, DiCamelli R, Ross RA, Stevenson LA, Murphy V, Pertwee RG, Campbell WB. Synthesis and characterization of potent and selective agonists of the neuronal cannabinoid receptor (CB1). J.Pharmacol.Exp.Ther. 1999; 289:1427-1433. [PubMed: 10336536]

Huffman JW, Liddle J, Yu S, Aung MM, Abood ME, Wiley JL, Martin BR. 3-(1',1'-Dimethylbutyl)-1deoxy-delta8-THC and related compounds: synthesis of selective ligands for the CB2 receptor. Bioorg.Med.Chem. 1999; 7:2905-2914. [PubMed: 10658595] 
Huffman JW, Zengin G, Wu MJ, Lu J, Hynd G, Bushell K, Thompson AL, Bushell S, Tartal C, Hurst DP, Reggio PH, Selley DE, Cassidy MP, Wiley JL, Martin BR. Structure-activity relationships for 1-alkyl-3-(1-naphthoyl)indoles at the cannabinoid $\mathrm{CB}(1)$ and $\mathrm{CB}(2)$ receptors: steric and electronic effects of naphthoyl substituents. New highly selective $\mathrm{CB}(2)$ receptor agonists.

Bioorg.Med.Chem. 2005; 13:89-112. [PubMed: 15582455]

Kawamura Y, Fukaya M, Maejima T, Yoshida T, Miura E, Watanabe M, Ohno-Shosaku T, Kano M. The CB1 cannabinoid receptor is the major cannabinoid receptor at excitatory presynaptic sites in the hippocampus and cerebellum. J.Neurosci. 2006; 26:2991-3001. [PubMed: 16540577]

Large M, Sharma S, Compton MT, Slade T, Nielssen O. Cannabis Use and Earlier Onset of Psychosis: A Systematic Meta-analysis. Arch.Gen.Psychiatry. 2011; 68:565-561.

Lefkowitz RJ, Shenoy SK. Transduction of receptor signals by beta-arrestins. Science. 2005; 308:512517. [PubMed: 15845844]

Macey TA, Ingram SL, Bobeck EN, Hegarty DM, Aicher SA, Arttamangkul S, Morgan MM. Opioid receptor internalization contributes to dermorphin-mediated antinociception. Neuroscience. 2010; 168:543-550. [PubMed: 20394808]

Mato S, Alberdi E, Ledent C, Watanabe M, Matute C. CB1 cannabinoid receptordependent and independent inhibition of depolarization-induced calcium influx in oligodendrocytes. Glia. 2009; 57:295-306. [PubMed: 18814177]

McGuinness D, Malikzay A, Visconti R, Lin K, Bayne M, Monsma F, Lunn CA. Characterizing cannabinoid CB2 receptor ligands using DiscoveRx PathHunter beta-arrestin assay. J.Biomol.Screen. 2009; 14:49-58. [PubMed: 19171920]

National Institute on Drug Abuse (NIDA). InfoFacts: Marijuana Abuse. 2009. p. 1-5.

Onaivi ES, Ishiguro H, Gong JP, Patel S, Meozzi PA, Myers L, Perchuk A, Mora Z, Tagliaferro PA, Gardner E, Brusco A, Akinshola BE, Hope B, Lujilde J, Inada T, Iwasaki S, Macharia D, Teasenfitz L, Arinami T, Uhl GR. Brain Neuronal CB2 Cannabinoid Receptors in Drug Abuse and Depression: From Mice to Human Subjects. PLoS.ONE. 2008; 3:e1640. [PubMed: 18286196]

Onaivi ES, Ishiguro H, Gong JP, Patel S, Perchuk A, Meozzi PA, Myers L, Mora Z, Tagliaferro P, Gardner E, Brusco A, Akinshola BE, Liu QR, Hope B, Iwasaki S, Arinami T, Teasenfitz L, Uhl GR. Discovery of the presence and functional expression of cannabinoid CB2 receptors in brain. Ann.N.Y.Acad.Sci. 2006; 1074:514-536. [PubMed: 17105950]

Roth BL. Irving Page Lecture: 5-HT(2A) serotonin receptor biology: interacting proteins, kinases and paradoxical regulation. Neuropharmacology. 2011; 61:348-354. [PubMed: 21288474]

Rutkowska M, Jachimczuk O. Antidepressant--like properties of ACEA (arachidonyl-2chloroethylamide), the selective agonist of CB1 receptors. Acta Pol.Pharm. 2004; 61:165-167. [PubMed: 15493300]

Shoemaker JL, Ruckle MB, Mayeux PR, Prather PL. Agonist-directed trafficking of response by endocannabinoids acting at CB2 receptors. J.Pharmacol.Exp.Ther. 2005; 315:828-838. [PubMed: 16081674]

Showalter VM, Compton DR, Martin BR, Abood ME. Evaluation of binding in a transfected cell line expressing a peripheral cannabinoid receptor (CB2): identification of cannabinoid receptor subtype selective ligands. J.Pharmacol.Exp.Ther. 1996; 278:989-999. [PubMed: 8819477]

Singh RK, Jia C, Garcia F, Carrasco GA, Battaglia G, Muma NA. Activation of the JAK-STAT pathway by olanzapine is necessary for desensitization of serotonin $2 \mathrm{~A}$ receptorstimulated phospholipase $\mathrm{C}$ signaling in rat frontal cortex but not serotonin2A receptorstimulated hormone release. J.Psychopharmacol. 2010; 24:1079-1088. [PubMed: 19304867]

Singh RK, Shi J, Zemaitaitis BW, Muma NA. Olanzapine increases RGS7 protein expression via stimulation of the Janus tyrosine kinase-signal transducer and activator of transcription signaling cascade. J.Pharmacol.Exp.Ther. 2007; 322:133-140. [PubMed: 17392403]

Trincavelli ML, Tuscano D, Cecchetti P, Falleni A, Benzi L, Klotz KN, Gremigni V, Cattabeni F, Lucacchini A, Martini C. Agonist-induced internalization and recycling of the human A(3) adenosine receptors: role in receptor desensitization and resensitization. J.Neurochem. 2000; 75:1493-1501. [PubMed: 10987829] 
Yang CH, Huang HW, Chen KH, Chen YS, Sheen-Chen SM, Lin CR. Antinociceptive potentiation and attenuation of tolerance by intrathecal beta-arrestin 2 small interfering RNA in rats.

Br.J.Anaesth. 2011; 107:774-781. [PubMed: 21926413] 

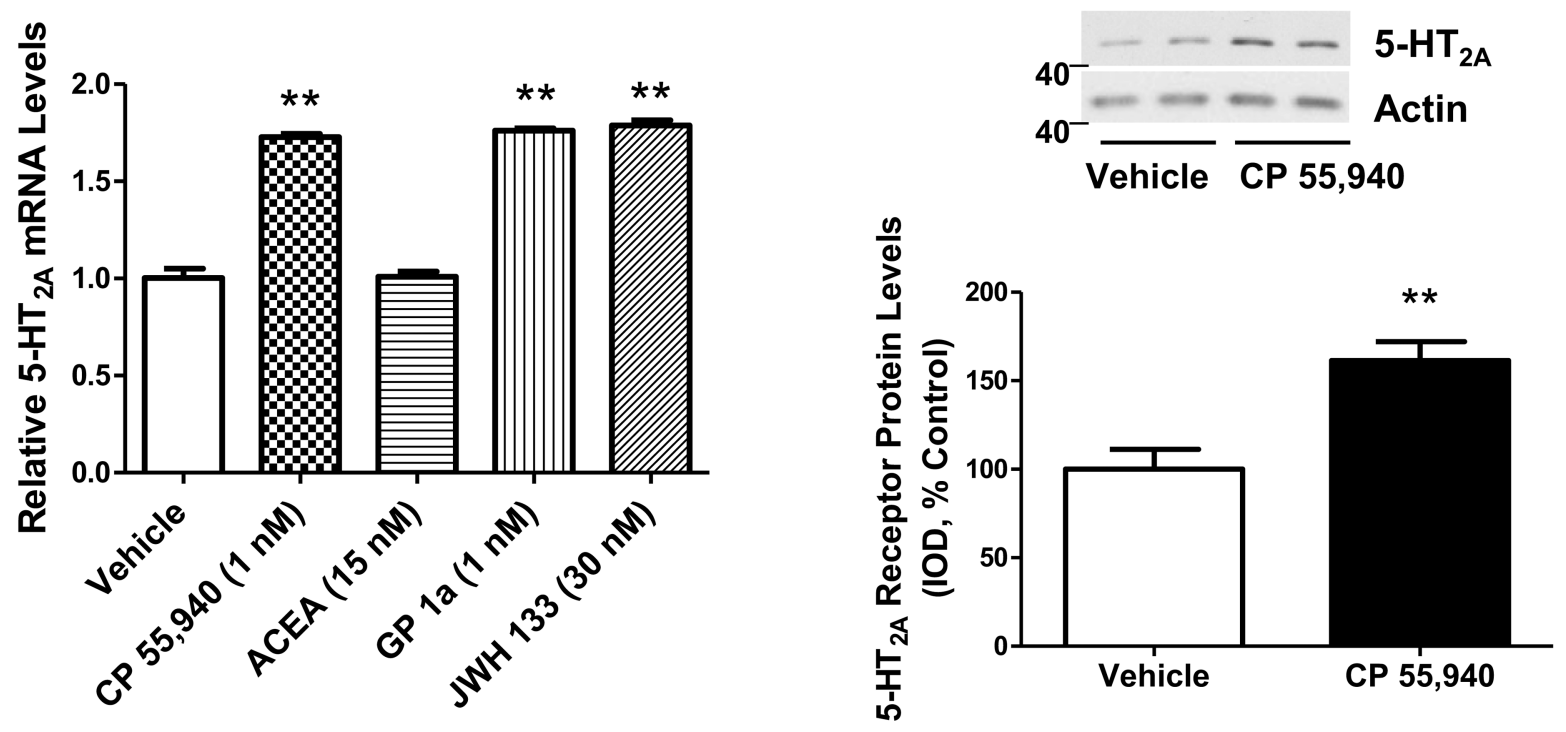

C
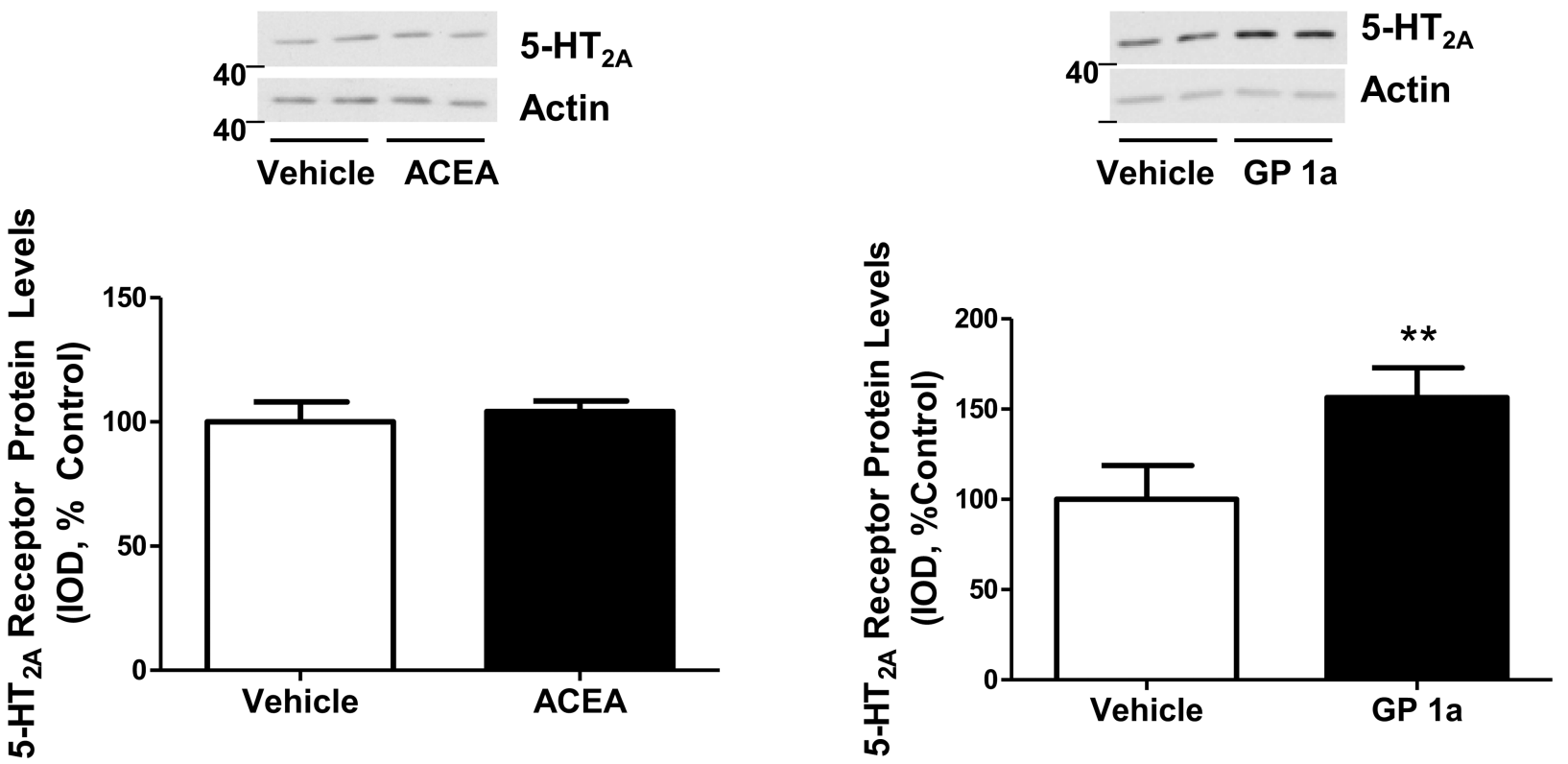

Figure 1. Cannabinoid-induced upregulation of $5-\mathrm{HT}_{2 \mathrm{~A}}$ receptors

(A) Increased 5- $\mathrm{HT}_{2 \mathrm{~A}}$ receptor mRNA levels in cells treated with either CP55,940, JWH 133, or GP1a. (**p<0.01 significant effect of CP55,940,JWH133, and GP1a treatment compared to vehicle-treated controls). (B) Increased membrane-associated $5-\mathrm{HT}_{2 \mathrm{~A}}$ receptor protein levels in cells treated with CP 55,940. (**p<0.01 significant effect of CP 55,940 treatment compared to vehicle-treated controls). (C) ACEA treatment does not alter membrane-associated 5- $\mathrm{HT}_{2 \mathrm{~A}}$ receptor protein levels ( $\left.\mathrm{p}>0.05\right)$. (D) Increased membraneassociated 5- $\mathrm{HT}_{2 \mathrm{~A}}$ receptor protein levels in cells treated with GP 1a. (**p<0.01 significant effect of GP 1a treatment compared to vehicle-treated controls). The data represent mean \pm $\operatorname{SEM}(n=3)$. 


\section{A}
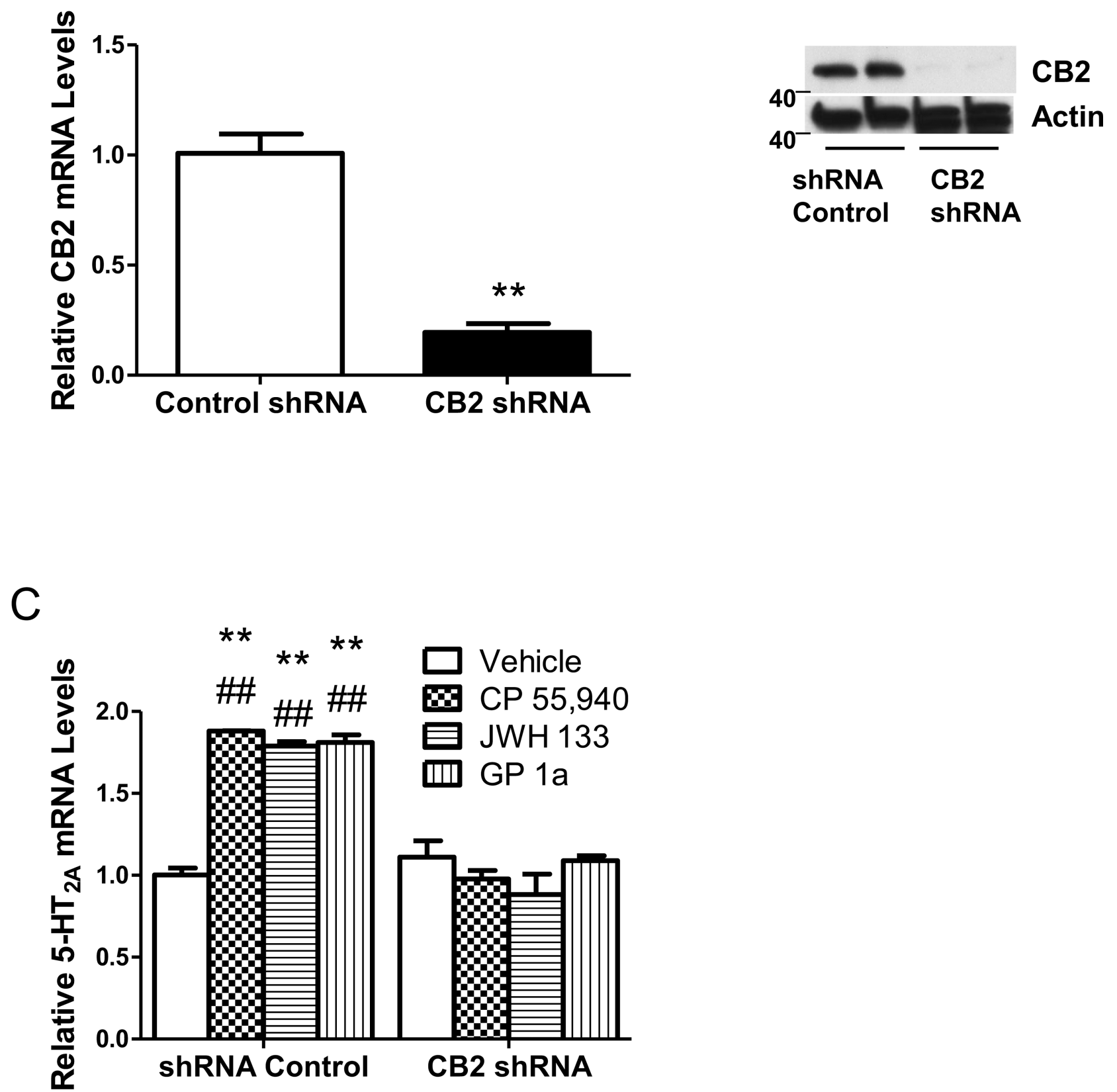

Figure 2. CB2 receptors are necessary for CP55,940, JWH133, and GP1a-induced upregulation of $5-\mathrm{HT}_{2 \mathrm{~A}}$ receptors

(A) Reduced CB2 mRNA levels in cells treated with CB2 shRNA lentiviral particles. (**p<0.01 significant effect of CB2 shRNA compared to control shRNA treated cells). (B) Reduced CB2 protein levels in cells treated with CB2 shRNA lentiviral particles compared to control shRNA lentiviral particle treated controls. (C) CB2 shRNA lentivirus transfection prevents CP55,940, JWH133 and GP1a-induced increases in 5- $\mathrm{HT}_{2 \mathrm{~A}}$ receptor mRNA. $* * \mathrm{p}<0.01$, significant effect of CP55,940, JWH133, and GP1a treatment on 5-HT $2 \mathrm{~A}$ receptor mRNA levels in control shRNA lentivirus transfected cells compared to vehicle-treated controls. \#\#p<0.01, significant effect of CB2 shRNA lentivirus transfection on the 
CP55,940, JWH133, and GP1a-induced upregulation of 5- $\mathrm{HT}_{2 \mathrm{~A}}$ receptors. The data represent mean $\pm \operatorname{SEM}(n=3)$. 
A

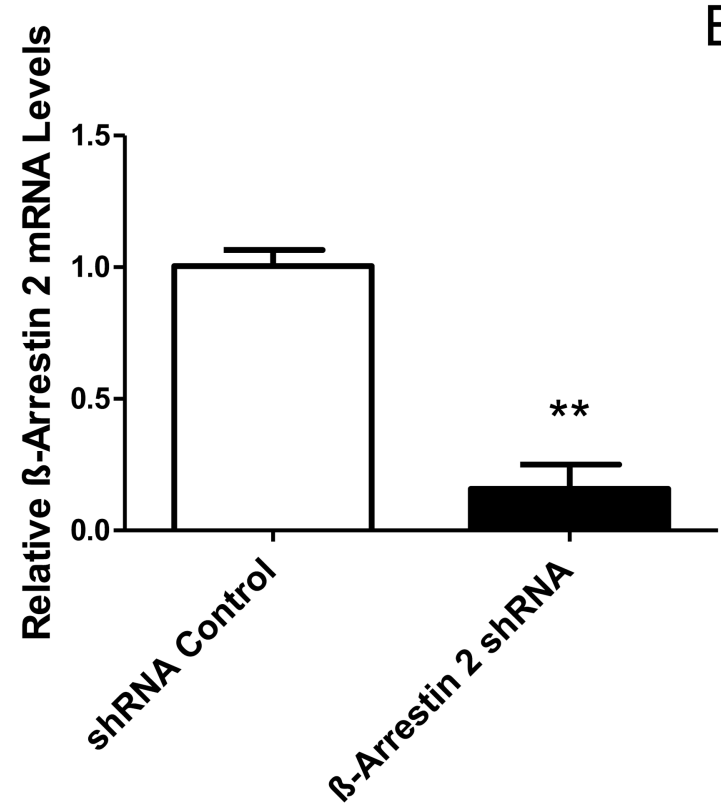

C

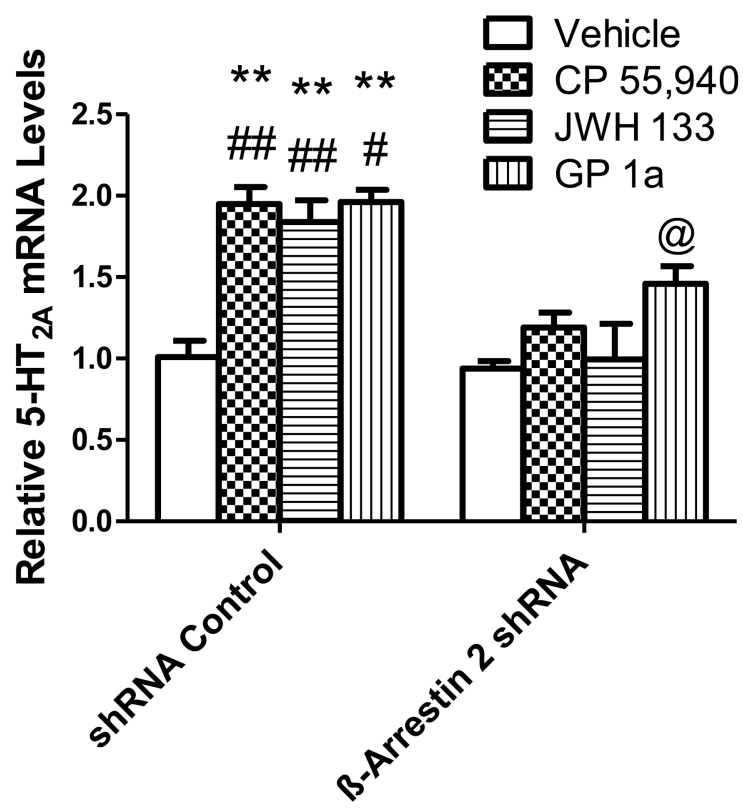

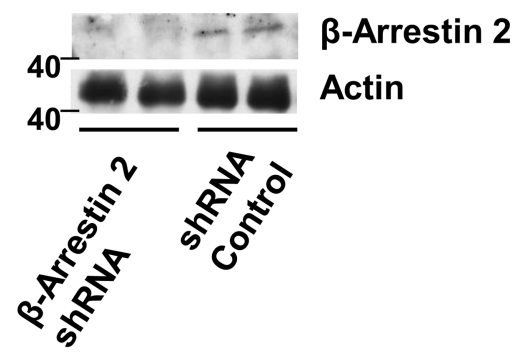

B 
CP55,940 and JWH133 or GP1a-induced upregulation of 5-HT2A receptors. @ $\mathrm{p}<0.05$, significant effect of GP 1a treatment in $\beta$-Arr2 shRNA transfected cells compared to vehicle-treated $\beta$-Arr2 shRNA transfected cells. The data represent mean $\pm \operatorname{SEM}(n=3)$. 
A

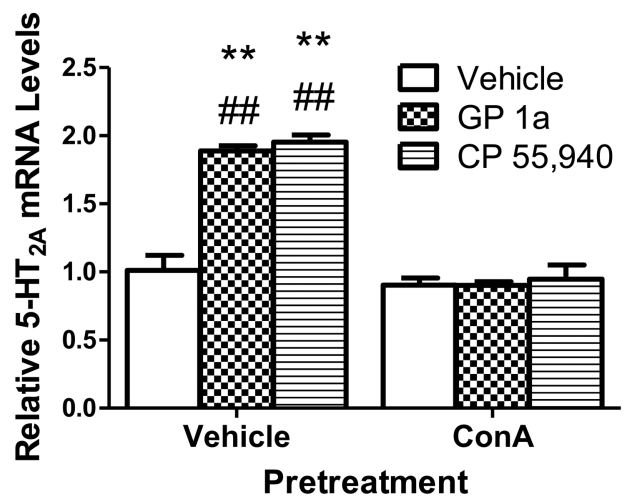

D

C internalization

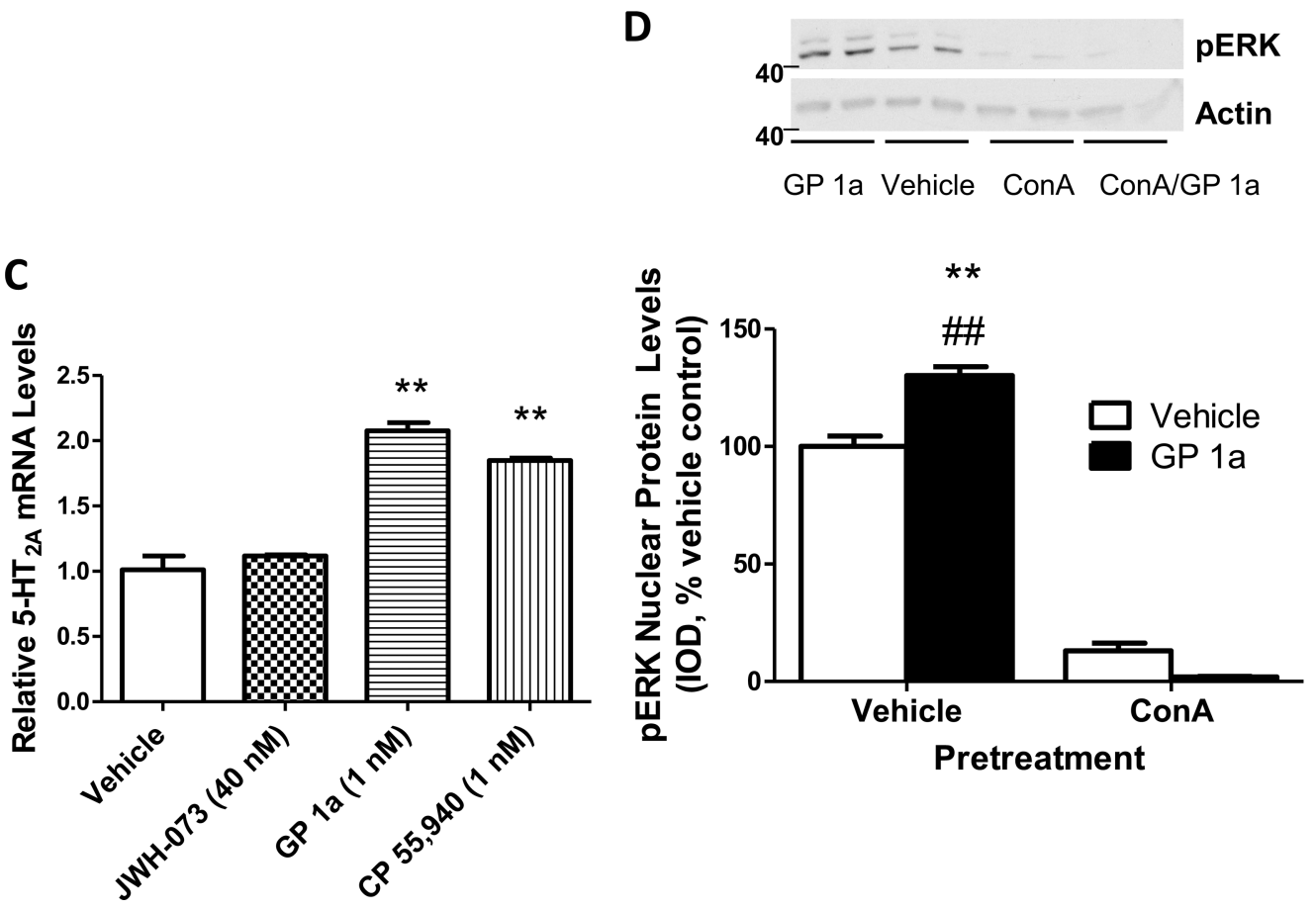

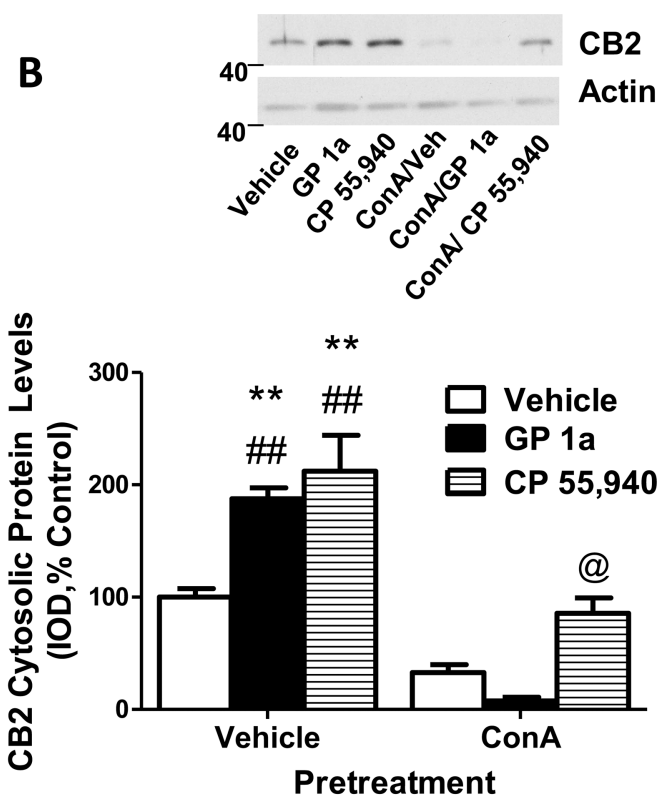

CB2

Actin

Figure 4. CP55,940 and GP1a may upregulate 5-HT $2 \mathrm{~A}$ receptors via CB2 receptor

(A) ConA pretreatment prevents CP55,940 and GP1a-induced increases in 5- $\mathrm{HT}_{2 \mathrm{~A}}$ receptor mRNA. ${ }^{* *} \mathrm{p}<0.01$, significant effect of CP55,940 and GP1a treatment on 5-HT $2 \mathrm{~A}$ receptor mRNA levels compared to vehicle-treated controls. \#\#p<0.01, significant effect of ConA pretreatment on the CP55,940 and GP1a-induced upregulation of 5- $\mathrm{HT}_{2 \mathrm{~A}}$ receptors. (B) ConA pretreatment prevents CP55,940 and GP1a-induced increases in cytosolic-associated CB2 receptor protein levels. **p<0.01, significant effect of CP55,940 and GP1a treatment on cytosolic CB2 receptor protein levels compared to vehicle-treated controls. \#\#p<0.01, significant effect of ConA pretreatment on the CP55,940 and GP1a-induced increases in 
cytosolic CB2 receptor protein levels. @ p $<0.05$, significant effect CP 55,940 treatment in ConA pretreated cells compared to ConA/vehicle or ConA/GP1a treated cells. (C) JWH-073 does not significantly $(\mathrm{p}>0.05)$ alter $5-\mathrm{HT}_{2 \mathrm{~A}}$ receptor mRNA levels. $* * \mathrm{p}<0.01$, significant effect of CP55,940 and GP1a treatment on 5- $\mathrm{HT}_{2 \mathrm{~A}}$ receptor mRNA levels compared to vehicle-treated controls. (D) ConA pretreatment prevents GP1a-induced increases in nuclear pERK. $* *$ p $<0.01$, significant effect of GP1a treatment on nuclear pERK levels compared to vehicle-treated controls. \#\#p<0.01, significant effect of ConA pretreatment on GP1ainduced increases in nuclear pERK levels. The data represent mean $\pm \operatorname{SEM}(n=3)$. 